ОСОБЛИВОСТІ РЕАКТИВНОЇ ТА ОСОБИСТІСНОЇ ТРИВОЖНОСТІ В ОСІБ ІЗ ПСИХОСОМАТИЧНИМИ НЕДОМАГАННЯМИ

\title{
FEATURES OF REACTIVE AND PERSONAL ANXIOUSNESS IN PERSONS WITH PSYCHOSOMATIC DISORDERS
}

У статті розглянуто результати теоретичного аналізу фракторів, що призводять до підвищеного тривожного стану, який може бути причиною виникнення психосоматичних порушень. Мета дослідження визначити рівень психосоматичних недомагань в осіб із різним ступенем тривожності. Для досягнення поставленої мети використовувалися такі методи: для дослідження рівня тривожності-методика Ч.Д. Спілбергера, для дослідження рівня психосоматичних недомагань - Гіссенівський опитувальник соматичних скарг.

Кореляційний аналіз показав, що показники тривожності реактивної й особистісно тісно корелюють між собою ( $r=0,60$ при $P<$ 0,01). На основі інтеркореляційного аналізу показників інтенсивності психосоматичних недомагань і тривожності з'ясувалося, що всі психосоматичні скараи корелюють як із реактивною, так $і$ з особистісною тривожністю. Представлено результати аналізу інтенсивності психосоматичних недомагань в осіб із різним ступенем тривожності, а саме: в осіб із високим рівнем особистісної тривожності за всіма без винятку шкалами середні величини психосоматичних недомагань $є$ достовірно $(P<0,05)$ вищими, а за шкалою «Тиск» або «lнтенсивність скарг» достовірність відмінностей за t-критерієм Стьюдента $P<0,01$. Психосоматичні недомагання тісніше пов'язані з особистісною тривожністю лише за параметрами ревматичних і серцевих скарг ( $r=0,31$ і 0,37 відповідно). Показники ревматичних і серцевих скарг мають слабші зв'язки з реактивною тривожністю, а до того ж під час перевірки їх достовірності за t-критерієм Стьюдента вони виявилися не достовірними $(P>0,05)$. Показники психосоматичних недомагань «виснаження», «шлункові скарги» й «тиск» тісніше пов'язані з реактивною, а не особистісною тривожністю.

Середні показники за шкалою «Тиск» в осіб із високою тривожністю становили 25,5 бала, а в іспитованих із низьким рівнем тривожноcmi - 14,2 бала. Такі дані дали змогу зробити висновок, що інтенсивність психосоматичних недомагань пов'язана з рівнем як реактивної, так й особистісної тривожності.
Ключові слова: реактивна тривога, особистісна тривожність, психосоматичні недомагання.

The paper aims to study the level of state and trait types of anxiety, as well as the level of psychosomatic disorders in people with different degrees of anxiety. The following methods were applied in the research: in order to study the level of state and trait anxiety State-Trait Anxiety Inventory by Spielberger was used, the psychosomatic aspects of physical disorders were investigated using the Giesener Beschwerdebogen - a questionnaire designed to detect a subjective map of patients' physical suffering. The carried out correlation analysis has shown that both the indicators of state and trait anxiety are closely correlated with each other $(r=0.60$ at $P<0.01)$. According to the correlation analysis of the data presented in Table 1, state anxiety index is much closer, as compared to the trait anxiety, associated with the indicator of psychosomatic disorders of "gastric complaints" type ( $r=0.46$ and 0.38 respectively). The indicator of "heart complaints" on the contrary, is more closely related to trait anxiety $(r=0.37)$. The Student $t$-test was used to verify the reliability of the results obtained. The analysis of the experiment results makes it possible to state that in the respondents with a high level of trait anxiety according to all scales without exception, the average values of psychosomatic disturbances are significantly $(P>0.05)$ higher, but according to the "Intensity of complaints" scale the validity of the differences according to Student's t-test was $P>0.01$ ). The average indicators according the "Pressure" scale in the subjects with the high anxiety level were 25.5 points, while those with the low anxiety level had 14.2 points. The same tendency is observed according to all scales, although the difference in other scales is not so pronounced.

According to inter-correlation analysis of the indicators of intensity of psychosomatic disturbances and anxiety, all psychosomatic complaints correlate both with state and trait types of anxiety. It has been concluded that the intensity of psychosomatic disturbances correlates with the level of both state and trait types of anxiety. It can also be concluded that people with high trait anxiety tend to have high state anxiety.

Key words: state anxiety, trait anxiety, psychosomatic disorders. аспірант кафедри психології

Черкаський національний університет імені Богдана Хмельницького
Постановка проблеми. Психологічні та психосоматичні розлади можуть виникати як результат протиріччя біологічної й соціальної еволюції людини, тобто з протиріч між способом життя сучасної людини та їі фізіологічними властивостями нервової системи або фізіолого-екологічного протиріччя, а також між соціальними стереотипами емоційного вираження й природними, фізіологічними механізмами емоційного реагування або соці- ально-екологічними протиріччями [4]. Отже, несприятливі соціально-екологічні умови, які спричиняють емоційне напруження й підвищену тривожність, можуть бути причиною виникнення психосоматичних недомагань.

Актуальність проблеми зумовила вибір теми дослідження.

Об'єктом дослідження є реактивна й особистісна тривожність у людей із психосоматичними розладами. 
Предметом дослідження є вплив тривожності на психосоматичні недомагання.

Постановка завдання. Завдання дослідження:

Дослідити величину рівня реактивної та особистісної тривожності.

Визначити рівень психосоматичних недомагань в осіб із різним ступенем тривожності.

Виклад основного матеріалу дослідження. Протиріччя соціально-екологічне пов'язане з протистоянням між природними інстинктами людини й соціальними нормами моралі. Соціально-екологічне протиріччя підсилюється й феноменами масової свідомості, що стикається з інстинктом самозбереження. У наш час це економічні потрясіння, загроза безробіття, невпевненість у завтрашньому дні. У період соціальної кризи зростанню такої напруженості сприяють і кризи соціальних інститутів суспільства, підвищення злочинності, загроза тероризму, війни тощо, особливо коли вони слугують предметом спекуляцій у засобах масової інформації. Усе це загалом може призвести до так званих соціально-стресових розладів [1].

Фізіолого-екологічні протиріччя загострюються у зв'язку з бурхливим розвитком науково-технічного прогресу й пов'язаними із цим змінами в стилі життя, який пред'являе неабиякі вимоги до нервової системи людини. Так, інформаційне перевантаження може призвести до інформаційного стресу з подальшим негативним впливом на психіку людини. До фізіолого-екологічних причин згубного впливу на психіку людини можна зарахувати й гіперрефлексію, тобто надмірну, нефізіологічну схильність до раціонального мислення з пригніченням його образно-інтуїтивних механізмів. У результаті небажаним психофізіологічним наслідком може бути дисбаланс функціональної асиметрії півкуль мозку, тривала підвищена активність лобових ділянок головного мозку або гіперфронтальність. [5]. Якщо людина не може адаптуватися до інформаційного навантаження, це може призвести до специфічного так званого інформаційного стресу, який призводить до підвищення емоційного супроводу мислення за рахунок негативних емоцій, передусім тривоги.

Зниження загальної фізичної працездатності й загального тонусу $є$ результатом гіподинамії. Гіподинамія є причиною не лише цих небажаних зрушень, а й зниження рефлекторної активації кори мозку та недостатньої рефлекторної стимуляції внутрішніх органів, що може бути причиною виникнення низки так званих класичних психосоматичних розладів. На виникнення цих психосоматичних розладів з еволюційно-фізіологічного погляду може вплинути й ортостатичне положення нашого організму, зокрема на виникнення захворювань серцево-судинної системи [2]. Варто нагадати, що, за даними ВО3, натепер найвища смертність через розлад серцево-судинної системи.

Надлишкова кількість у сучасних стравах легкозасвоюваних вуглеводів і синтетичних інгредієнтів призводить до порушень внутрішньої екології організму - дисбалансу мікрофлори. Це, у свою чергу, призводить до таких соматопсихічних наслідків, як синдром дефіциту задоволення, зниження інформаційної цінності страви.

Такі соціально-екологічні фактори, як подовжений світловий режим, переміщення з високими швидкостями, інтенсивний режим життя, призводять до порушень індивідуальних біоритмів, зрушуючи їх синхронність із природними - біологічними. Це може бути причиною розбалансованої нейрогуморальної регуляції, яка здійснюється на гіпоталамо-гіпофізарному рівні [7]. Крім цього, проміжний мозок $€$ центральною ділянкою під час розвитку емоціонального стресу. Усі ці несприятливі соціально-екологічні умови можуть призводити до емоціонального напруження, підвищеної тривожності й вірогідних психосоматичних розладів.

Для дослідження рівня тривоги і тривожності застосовували шкали розроблені Ч.Д. Спілбергером у 1966-1973 рр. Згідно з концепцією Спілбергера, варто розрізняти тривогу як стан і тривогу як особистісну властивість.

Тривога - це реакція на небезпеку, що загрожує, реальну чи уявну, емоційний стан дифузного безоб'єктного страху, що характеризується невизначеним відчуттям загрози, на відміну від страху, який являє собою реакцію на реальну небезпеку. Тривожність - індивідуальна психологічна особливість, яка проявляється в підвищеній схильності відчувати неспокій у різноманітних життєвих ситуаціях, у тому числі й тих, об'єктивні характеристики яких цього не передбачають. На думку автора, існує можливість виміру відмінностей між двома видами психічного прояву, а саме між тимчасовими швидкоплинними особливостями й відносно постійною схильністю. Розуміння тривоги в теорії Спілбергера визначається такими положеннями:

1. Ситуації, що становлять для людини певну загрозу або особистісно значиму, яка визиває в неї стан тривоги. Суб'єктивно тривога відчувається як неприємно емоційне переживання різної інтенсивності.

2. Інтенсивність відчуття тривоги пропорційна величині загрози або значимості причини переживання. Від цих факторів залежить тривалість переживання стану тривоги.

3. Люди з високою тривожністю сприймають ситуації або обставини, які потенційно містять можливість невдачі або загрози, більш інтенсивно. 
4. Ситуація тривоги супроводжується змінами в поведінці або ж мобілізує захисні механізми [6].

Методика дослідження тривожності Спілбергера являє собою комбіновану шкалу з трьох відомих тестів: шкали тривожності Кеттелла та Шатра, «Прояву тривожності», шкали Тейлор і шкали тривожності Велша. Шкала складається з двох частин по 20 завдань у кожній. Перша шкала призначена для визначення того, як іспитований відчуває себе в момент обстеження, тобто для діагностики актуального стану, а завдання другої шкали спрямовані на аналіз того, як суб'єкт відчуває себе зазвичай, тобто діагностується тривожність як особистісна властивість.

Кожна шкала має свою інструкцію, тривалість обстеження становить близько 5-8 хвилин. Кожне питання оцінюється за 4-бальною шкалою. Вербальна інтерпретація позицій оціночної шкали в першій і другій частинах різна. Опитувальник допускає індивідуальне й групове використання. У нашому випадку застосовувалося індивідуальне використання.

Методика Спілбергера адаптована російською мовою Ю.Л. Ханіним у 1978 році [3]. Ним проведена стандартизація методики й вироблені орієнтовні нормативи. Українською мовою методика адаптована автором статті, хоча іспитованим пропонувалися водночас як російськомовний варіант, так й україномовний [5].

Тестування проводилося на стандартизованому бланку, розробленому спеціально для таких цілей автором статті.

Психосоматична зумовленість фізичних недомагань досліджувалася за допомогою Гісенівського опитувальника - анкети, що призначений для виявлення суб'єктивної картини фізичних страждань хворих, який запропонували Є. Брюхлер і Дж. Снер у 1967 році [3].

Стандартизація проводилася на вибірці в Німеччині (1601 особа) та пацієнтах психосоматичної клініки Гісенівського університету (4076 осіб).

У Росії проводилася стандартизація опитувальника на двох вибірках: I - здорові іспитовані в кількості 286 осіб, II - пацієнти з невротичними та психосоматичними розладами (467 осіб). Дослідження психометричних характеристик Гісенівським опитувальником соматичних скарг мало на меті й розрахунки його валідності та надійності.

Опитувальник складається 3 переліку 57 скарг, які можна зарахувати до таких сфер, як загальне самопочуття, вегетативні розлади, порушення функцій внутрішніх органів. Ступінь їх інтенсивності оцінюється за 5-бальною шкалою. Окрім скарг, виявляється їх зумовленість психічними або фізичними факторами, на думку пацієнта. Автори методики за допо- могою факторного аналізу виокремили чотири основних та одну додаткову шкали:

Шкала 1. «Виснаження» (В) - характеризує неспецифічний фактор виснаження, що вказує на загальну втрату життєвої енергії, потребу в допомозі.

Шкала 2. «Шлункові скарги» (Ш) - відображає синдром нервових (психосоматичних) шлункових недомагань.

Шкала 3. «Ревматичний характер» (Р) - відображає суб'єктивні страждання пацієнта, що мають алергічний або спастичний характер.

Шкала 4. "Серцеві скарги» (С) - указує на те, що пацієнт локалізує свої недомагання здебільшого в серцево-судинній сфері.

Шкала 5. «Інтенсивність скарг» або «Тиск» (Т) - характеризує загальну інтенсивність скарг.

Усі шкали опитувальника мають розподіл, близький до нормального.

Іспитованими були студенти стаціонарної та заочної форми навчання віком 18-43 років, різних факультетів і курсів університету, загальна кількість - 187 осіб.

Обробка отриманих даних проводилася 3 використанням комп'ютерних програм Statistica v. 7.0 i SPSS v.23.

На основі інтеркореляційного аналізу показників інтенсивності психосоматичних недомагань і тривожності з'ясувалося, що всі психосоматичні скарги корелюють як із реактивною, так і з особистісною тривожністю (таблиця 1). Із даних інтеркореляційної матриці видно, що існує тісний зв'язок між реактивною й особистісною тривожністю. 3 таблиці 1 випливає, що й показники психосоматичних недомагань мають тісний кореляційний зв'язок між собою. Психосоматичні недомагання тісніше пов'язані з особистісною тривожністю лише за параметрами ревматичних і серцевих скарг ( $r=0,31$ і 0,37 відповідно). Показники ревматичних і серцевих скарг мають слабші зв'язки з реактивною тривожністю, а до того ж під час перевірки їх достовірності за t-критерієм Стьюдента вони виявилися недостовірними ( $\mathrm{P}$ $>0.05)$. Показники психосоматичних недомагань «виснаження», «шлункові скарги» й «тиск» тісніше пов'язані з реактивною, а не особистісною тривожністю.

Кореляційний аналіз показав, що показники тривожності реактивної й особистісної тісно корелюють між собою $(r=0,60$ при $\mathrm{P}<0,01)$, що видно з таблиці 1. Звідси можна зробити висновок, що автор методики вказує на принципову відмінність реактивної тривожності від тривожності особистісної (перша, на думку автора, характеризує стан досліджуваного на момент обстеження, а друга - як особистісна (тобто більш стійка) властивість, але все ж таки вони між собою тісно взаємопов'язані. Мабуть, важко уявити людину з високою осо- 
Результати інтеркореляційного аналізу досліджуваних величин

Таблиця 1

\begin{tabular}{|l|c|c|c|c|c|c|}
\hline \multicolumn{1}{|c|}{ Виснаження } & Виснаження & Шлункові & Ревматичні & Серцеві & Тиск & Реактивна \\
\hline Шлункові & 0,46 & & & & & \\
\hline Ревматичні & 0,48 & 0,57 & & & & \\
\hline Серцеві & 0,53 & 0,51 & 0,67 & & & \\
\hline Тиск & 0,77 & 0,78 & 0,82 & 0,74 & & \\
\hline Реактивна & 0,45 & 0,46 & 0,28 & 0,25 & 0,46 & \\
\hline Особистісна & 0,44 & 0,38 & 0,31 & 0,37 & 0,45 & 0,60 \\
\hline
\end{tabular}

бистісною тривожністю й незначною реактивною, принаймні в нашому дослідженні таких не помічено.

Як свідчить кореляційний аналіз даних, поданих у таблиці 1, показник реактивної тривожності значно тісніше порівняно з особистісною пов'язаний із показником психосоматичних недомагань «шлункові скарги» (r= 0,46 і 0,38 відповідно). Показник «серцевих скарг», навпаки, тісніше пов'язаний з особистісною тривожністю $(r=0,37)$ [8].

Згідно з методикою Ч.Д. Спілбергера, модифікованою і стандартизованою Ю.Л. Ханіним, іспитовані поділені на групи відповідно до рівня прояву тривожності. На двох вибірках із крайніми проявами тривожності, а саме з низьким і високим рівнями тривожності, за показниками середніх величин інтенсивності психосоматичних скарг простежені відмінності.

Отримані нами результати експериментальних досліджень дають підстави стверджувати, що середні показники інтенсивності психосоматичних скарг мають достовірні відмінності в груп із різним рівнем тривожності. Така закономірність спостерігається в групах як із реактивною, так і з особистісною тривожністю. Оскільки закономірності розподілу груп і залежності психосоматичних недомагань мають однакову тенденцію, ми подаємо дані лише для показників особистісної тривожності.

Аналіз результатів досліджень дає право стверджувати, що в осіб із високим рівнем особистісної тривожності за всіма без винятку шкалами середні величини психосоматичних недомагань були достовірно $(\mathrm{P}<0.05)$ вищими, а за шкалою «Тиск» або «Інтенсивність скарг» достовірність відмінностей за t-критерієм Стьюдента становила $\mathrm{P}<0.01$. Середні показники за шкалою «Тиск» в осіб із високою тривожністю становили 25,5 бала, а в іспитованих із низьким рівнем тривожності - 14,2 бали. Така сама тенденція спостерігається по всіх шкалах, щоправда, відмінності за іншими шкалами не так яскраво виражені.

Отримані дані дали підставу зробити припущення, що інтенсивність психосоматичних недомагань певною мірою пов'язана з рівнем як реактивної, так й особистісної тривожності.
Висновки 3 проведеного дослідження. За результатами дослідження можна зробити такі висновки: люди з високою особистісною тривожністю мають, як правило, і високу реактивну тривожність. Інтеркореляційний аналіз даних дає підстави зробити припущення, що як реактивна, так й особистісна тривожність тісно взаємопов'язані між собою, що, на наш погляд, указує на спільний генезис цієї властивості в досліджуваних.

Отримані результати інтеркореляційного аналізу, а також аналізу відмінностей середніх величин в осіб із різним рівнем тривожності дає підстави стверджувати, що між тривожністю й досліджуваними психосоматичними недомаганнями існує певний зв'язок. Наші дослідження не дають відповіді на питання, що є першопричиною виникнення психосоматичних недомагань. Залишається невідомо, чи підвищена тривожність $є$ причиною виникнення психосоматичних страждань, чи психосоматичні недомагання $є$ причиною підвищеної тривожності. Але якщо виходити з концепції Ч.Д. Спілбергера, що особистісна тривожність $€$ властивістю певною мірою детермінованою, то можна зробити припущення, що саме вона може впливати на розвиток психосоматичних недомагань. Якраз у цьому у полягає перспектива подальшої роботи в цьому напрямі.

\section{ЛІТЕРАТУРА:}

1. Александровский Ю.А. Пограничные психические расстройства. Ростов-на-Дону : Феникс, 1997. 576 C.

2. Белкания Г., Дарцмелия В. Гипертония и прямохождение. Наука и жизнь. 1986. № 2.

3. Бурлачук Л.Ф., Морозов С.М. Словарь-справочник по психодиагностике. Санкт-Петербург : Питер, 2001. 528с.: ил.

4. Сандомирский М.Е. Состояние психической адаптации в условиях хронического психоэмоционального стресса в связи с личностно-типологическими характеристиками : дисс. ... канд. мед. наук. Москва, 2000. 289 с.

5. Харченко Д.М. Психосоматичні розлади. Теорії, методи діагностики, результати досліджень : навчальний посібник. Київ : Видавничий дім «Слово», 2015. $280 \mathrm{c}$

6. Шульц Л. Язык интуиции. Москва : ЭКСМОПресс, 2002. 448 c. 


\section{ГАБІТУC}

7. Spielberger C.D., Gorsuch D.L., Lushene R.E. Manual for the State-Trait Anxiety Inventory. Palo Alto : Consulting Psychologists Press, 1970.

8. Kharchenko D.M., Chystovska Yu.Yu. Correlation of Anxiety and Psychosomatic Disturbances. Наука i освіта : науково-практичний журнал Південноукра- їнського національного педагогічного університету імені К.Д. Ушинського. Серія «Психологія». 2017. № 9. С. 26-29.

9. Ustun T.B., Sartorius N. Mental Illness in General Health Care: An International Study. Chichester: John Wiley \& Sons. 1995. 235 p. 